Зайцева, Маргарита, і Пелепейченко, Людмила. «Специфіка наративу в судовому дискурсі США». Лінгвостилістичні студї, вип. 14, 2021, с. 46-60.

Zaitseva, Margaryta, and Pelepeychenko, Liudmyla. "Specificity of Narrative in US Courtroom Discourse". Linguostylistic Studies, iss. 14, 2021, pp. 46-60.

УдК 811.111.2'42

https://doi.org/10.29038/2413-0923-2021-14-46-60

\title{
СПЕЦИФІКА НАРАТИВУ В СУДОВОМУ ДИСКУРСІ США
}

\author{
Маргарита Зайцева \\ Національний юридичний університет імені Ярослава Мудрого, \\ Харків, Україна
}

\section{Людмила Пелепейченко}

Національна академія Національної гвардії України,

Харків, Україна

\begin{abstract}
Стаття присвячена виявленню специфічних ознак наративу в дискурсі змагальної судової системи. Показано, що в судовому наративі виокремлюються константні і змінні ознаки, обгрунтовано їхні характеристики. Доведено, що зміст наративу та комунікативні стратегії, тактики, ходи відрізняються у обвинувачів і адвокатів: основною специфічною ознакою наративу обвинувачів $\epsilon$ синкретизм функцій наративу і персуазиву, а адвокатів - синкретизм функцій наративу, персуазиву та рефутативу.
\end{abstract}

Ключові слова: судовий дискурс, наратив, специфічні ознаки, комунікативні стратегії, стратагеми, соціологеми.

\section{SPECIFICITY OF NARRATIVE IN US COURTROOM DISCOURSE}

\author{
Margaryta Zaitseva \\ Yaroslav Mudryi National Law University, Kharkiv, Ukraine

\section{Liudmyla Pelepeychenko} \\ National Academy of the National Guard of Ukraine, Kharkiv, Ukraine
}

The article elucidates the analysis of legal language used in the courtroom settings.

In the focus are specific features of the narrative in US courtroom discourse. The study has proved that the use of the narrative in courtroom discourse is dependent on the peculiarities of social, pragmatic, and linguistic contexts. In terms of this approach, sustainable and variable features of the courtroom narration are distinguished. They include: 1) the theme of the story - the courtroom narration is a story about the circumstances of the crime, the defendant, or the victim; 2) the aims of the participants - they are contradictory for the prosecutor because it is a kind of competition, a battle of narratives in which the strongest one wins; 3 ) the speech etiquette; 4) the intertextual links of the courtroom narration - it always appeals to real facts and normative texts (laws, criminal code); 5) whether the system is competitive or non-adversarial. The attributes are, firstly, communicative strategies, tactics,

( ) Зайцева М., Пелепейченко Л., Волинський національний університет імені Лесі Українки, 2021.

Це стаття відкритого доступу на умовах СC BY-NC 4.0 
stratagemes, the non-verbal expression, secondly, social stereotypes relevant to the historical era in which the trial takes place, and thirdly, the value priorities of the country. The study has revealed that the content of the prosecutors' and lawyers' narrative is different. The prosecutors' narrative is characterised by the following features: an appeal to the ideological attitudes of society during the relevant historical period (social context); the use of a detailed strategy with an emphasis on the guilt of the defendants; the use of manipulative tactics and the actualisation of the stratagems "empathy", "figurative evaluation" and "concealing specific facts" (pragmatic context); syncretism of the functions of the narration and the persuasion; extensive use of emotive means of language; implicit opposition of the symbols of "protection", "life values" - "murder" (linguistic context). The specificity of the lawyer's narrative is determined by the following attributes: reliance on the value priorities of society, including those associated with the attribute of professionalism (social context); the use of the tactics of approaching the audience; communicative tactics of appeal to common moral values; and the stratagems "empathy", "imaginative assessment" and "rational assessment" (pragmatic context); the two-pronged orientation of the narrative; the actualisation of associative semantic components of the meanings of words and phrases, semantic evaluation, the repetition of words that emphasise the main priorities of society (linguistic context).

Key words: courtroom discourse, narrative, specific features, communicative strategies, stratagems, sociologemes.

Вступ. Наратив - розповідь із поясненнями, деталізацією, образним описом фактів, явищ, подій - супроводжує всі сфери діяльності людей. Не дивно, що названий феномен вивчається в різних наукових галузях: літературознавстві (Литературный), мовознавстві (Бистров; Куковська; Лісанець; Палашевська; Пелепейченко; Schiff; Burns; Griffin), філософії (Можейко), психології (Чепелєва, Смульсон, Шиловська, і Гуцол). У кожній із галузей він проявляє певну специфіку, яка на сьогодні вивчена ще недостатньо, хоча часто саме майстерно побудована розповідь визначає успішність досягнення поставленої мети у будь-якій царині. Сьогодні виявлення галузевої специфіки наративу постає як проблема, що потребує осмислення, спрямованого на розроблення рекомендацій щодо використання названого мовного жанру в різних видах діяльності соціуму. Особливо важливим майстерне володіння механізмами побудови наративу необхідне в тих типах дискурсів, які пов'язані з комунікативним впливом на окрему людину, аудиторію чи маси. Саме до таких дискурсів належить і судовий, у якому наратив здатен визначити долю людини. Невдало побудований наратив прокурора може стати причиною виправдання злочинця, а помилки в побудові наративу адвоката - засудження безневинної людини. Отже, виявлення специфіки вказаного жанру в різних сферах діяльності, а особливо в судовій, постає як актуальне питання, що вимагає не відкладного рішення.

Важливість осмислення комунікативної специфіки в судовій діяльності стала одним із факторів, що зумовив формування нової наукової парадигми - юридичної лінгвістики, діяльність у якій унеможливлюється без комунікативної взаємодії. У працях Ю. Прадіда, О. Діомідової, О. Мінченко, І. Царьової, Дж. Коттерілла та інших науковців 
переконливо доведена необхідність досліджень у названій сфері. У теоретичних джерелах подане визначення поняття юридичної лінгвістики, зокрема і судової (Георгієвська; Діомідова; Зайцева, і Липко; Карасик; Кобзєва; Палашевська; Прадід); виявлено окремі ознаки еволюції мовних жанрів в судовому дискурсі (Доценко; Зайцева, і Липко). Дослідження проводились на матеріалі різних мов: англійської (Бистров; Георгієвська; Зайцева, і Липко; Кобзєва), російської (Діомідова; Карасик; Палашевська), української (Доценко), проте специфіка наративу вивчена недостатньо, зокрема i стосовно англомовного судового дискурсу. Викладені спостереження враховані у формулюванні мети та завдань нашого дослідження.

Мета дослідження - виявити специфічні ознаки наративу в судовому дискурсі США. Досягнення сформульованої мети можливе за умови поетапного виконання низки завдань. Передусім слід уточнити визначення понять судового дискурсу, наративу загалом і судового наративу зокрема, а також обгрунтувати вибір методів аналізу матеріалу. Потім слід відтворити структуру судового дискурсу та подати типізовану характеристику трьох його контекстів. Далі вважаємо за необхідне виявити особливості наративу у виступах прокурорів, з одного боку, адвокатів, з другого. На останньому етапі аналізу маємо встановити специфічні ознаки, що притаманні судовому наративу загалом.

Матеріал і методи дослідження. Матеріалом для дослідження слугували тексти виступів прокурорів та адвокатів на реальних судових процесах (Amadou Diallo Trial) та тих, що відтворені в художній творчості (художній літературі (Harper), кінофільмах (Devil's Advocate; Find Me Guilty)).

Уточнення позиції авторів цієї статті щодо визначення поняття судового дискурсу та судового наративу здійснювалось в процесі аналізу дефініцій названих понять, представлених у теоретичних джерелах, 3 використанням методів зіставлення (зіставлялись підходи до інтерпретації понять та типи ознак аналізованих феноменів, що акцентовані різними авторами), узагальнення (узагальнювались спільні й відмінні погляди авторів), аргументації (в обгрунтуванні власних тлумачень). У виконанні інших завдань було обрано дискурсивних підхід, який визначив структуру аналізу згідно 3 концепцією Т. ван Дейка: виокремлення контекстів трьох різновидів: соціального, прагматичного і лінгвального (Дейк). Названий підхід зумовив зміст основоположної гіпотези дослідження: специфіка судового наративу та фактори його успішного впливу на присяжних і суддю проявляються в кожному з трьох видів дискурсивного контексту. Метод моделювання слугував у формуванні структури дослідження за такими векторами: виявлення специфіки судового дискурсу загалом - судового наративу за промовами обвинувачів - за промовами адвокатів - узагальнення. Типізована характеристика трьох контекстів дискурсу створювалась із 
використанням методу проєктування: результати спостережень за структурою реальних судових процесів США проєктувались на кожний із названих контекстів судового дискурсу. У виявленні особливостей промов обвинувачів та адвокатів були використані прийоми компонентного аналізу: виділялись ознаки, що являють собою компоненти контекстів (соціологеми, стратагеми), а в лінгвальному контексті - семантичні компоненти (семи) значень слів та словосполучень, які забезпечують ефективність упливу на аудиторію. Метод класифікації слугував у виокремленні типів специфічних ознак судового наративу та дискурсу загалом, а метод узагальнення - в підготовці висновків за результатами дослідження.

Результати дослідження та дискусія. Поняття наративу помітно еволюціонувало: від власне літературного терміну, що позначав «увесь текст епічного твору, за винятком прямої мови персонажів; зображення дій та подій у часовому зрізі, опис, міркування» (Лингвистический 280) воно перейшло до багатоаспектного феномена, який посів своє місце в різних науках, репрезентуючи в кожній із них дещо різні уявлення. Незмінними залишились тільки категоріальні ознаки - «розповідь» та «текст розповіді». Відмінності у дефініціях пояснюються передусім тим, що кожна з наук акцентувала в інтерпретації увагу на предметі відповідної наукової парадигми, функціях, які виконує наратив, та інших ознаках. Визначення наративу в різних наукових парадигмах, спільні ознаки й відмінності уже узагальнювались у теоретичних джерелах (Пелепейченко), тому в нашій статті розглянуто питання, які 3 тих чи інших причин опинилися поза полем зору дослідників. Усі автори зафіксували значне поширення сфер вивчення наративу. Вказаний факт мав і деякі негативні наслідки: поняття стало нечітким, занадто широким, на що зверталась увага науковців неодноразово (Пелепейченко; Herman; Schiff). Так, Брайян Шифф відзначає: «термін «розповідь» настільки поширений, що слово стало надмірно розтягнутим. Його значення $є$ розмитим» (Schiff), і з цим важко не погодитись. У нашій праці визначаємо наратив як складовий елемент дискурсу, що являє собою усний чи письмовий текст, у якому подана розповідь про факти, події, явища з більшим чи меншим ступенем образності, деталізації та пояснення.

Отже, ми приєднуємось до твердження, що наратив є дискурсивним утворенням (Пелепейченко), а відтак маємо викласти наше розуміння поняття дискурсу. Із численної кількості інтерпретацій ми обираємо ту, в якій дискурс представлено як зв'язний текст у сукупності 3 екстралінгвістичними - прагматичними, соціокультурними, психологічними й ін. факторами; текст, узятий в аспекті події; мовлення, розглянуте як цілеспрямована соціальна дія, як компонент, що бере участь у взаємодії людей і механізмах їхньої свідомості (когнітивних процесах) (Лингвистический 136-7). Ознаки, подані в дефініції, певним чином співвідносяться з трьома видами контекстів, про які йшлося вище. Їхній 
зв'язок ми трактуємо так. Соціальний контекст належить до екстралінгвістичних ознак, що репрезентують умови, в яких відбувається комунікативна подія. Різні ознаки соціального контексту ми номінуємо як соціологеми; до них належать такі: історичний період, в який відбувається судовий процес; ідеологічні установки суспільства, що превалюють у відповідний період; особливості комунікативної культури країни, їі ціннісні пріоритети; тип судової системи (змагальна чи дорадча); учасники (агенти) процесу. Лінгвальний контекст розглядаємо як власне текст у формі наративу, персуазиву, рефутативу і т. ін.

Прагматичний контекст є тим елементом, що об'єднує два інших в межах дискурсу: окремі його ознаки маніфестують умови дискурсу (йдеться про основну мету та інтенції мовця на різних етапах комунікації), а інші - мовно-комунікативні аспекти (маємо на увазі комунікативні стратегії, тактики, ходи, оскільки вони в той чи інший спосіб виражені через мовні одиниці). Окремі ознаки прагматичного контексту загалом номінуємо терміном «дискурсеми», а ознаки комунікативних стратегій «стратагеми» (Воеводин), оскільки вважаємо, що в наративі можуть бути поєднані окремі ознаки різних комунікативних стратегій. Судовий дискурс визначаємо як комунікативну подію, що відбувається в умовах судового процесу. Він має специфіку у всіх трьох типах контекстів, названих вище. Соціальний контекст судового дискурсу характеризується низкою константних ознак: усталеним сценарієм, чітко розмежованими статусними ролями і функціями учасників (агентів) (Доценко; Карасик; Кобзєва; Палашевська; Burns; Cotterill), ієрархією статусних ролей (головний - суддя; решта агентів підпорядковані тільки йому). Змінними ознаками в контексті названого типу є види звинувачення та обставини, в яких здійснювався злочин. Прихованим елементом соціального контексту в судовому дискурсі $\epsilon$ істина, яка має бути доведена прокурором чи адвокатом, а пресуппозиційним - закон, право і ціннісні пріоритети суспільства. Ознаки прагматичного контексту, що звернені до соціального, $\epsilon$ так само чітко визначеними і усталеними: іллокутивна мета обвинувача довести факт провини; адвоката - довести факт відсутності провини або наявності обставин, що іï пом'якшують. Змінними ознаками $\epsilon$ ті, що звернені до лінгвального контексту, тобто комунікативні стратегії, тактики і ходи агентів. У лінгвальному контексті усталеними ознаками $€$ мовні формули етикету, змінними - мовні засоби, що вербалізують стратегії, тактики, ходи. О.Доценко відзначає: «Етикетні мовленнєві жанри нетипові для судового дискурсу, однак ритуальність (на нашу думку, таке найменування є більш прийнятним, оскільки норми поведінки, зокрема й комунікативної, в суді $\epsilon$ чітко регламентованими, прописаними у нормативних актах, на відміну від норм етикету, які $\epsilon$ неписаними) $\epsilon$ елементом інформативних та імперативних жанрів» (4).

Схарактеризовані особливості судового дискурсу зумовлюють i специфіку судового наративу: у ньому теж можна виділити усталені 
ознаки і змінні. До усталених належать такі: 1) тема розповіді (у будьякому разі судовий наратив являє собою розповідь про умови скоєння злочину та про самого підсудного чи потерпілого); 2) цілі учасників судового процесу - вони описані вище; 3) мовні формули етикету; 4) інтертекстуальні зв'язки судового наративу - він завжди апелює до реальних фактів і нормативних текстів (закони, кримінальний кодекс); 5) тип судової системи - змагальна чи дорадча. Змінними є, по-перше, комунікативні стратегії, тактики, ходи та їхнє мовне вираження, по-друге, соціальні стереотипи, актуальні на історичну добу, в умовах якої відбувається суд, по-третє особливості комунікативної культури країни.

Розглянемо за схарактеризованою моделлю судовий процес по справі Амаду Діалло - про вбивство поліцейськими чорношкірого хлопця, який підозрювався у наркоторгівлі. Вбивство скоєно 4 лютого 1999 року в окрузі Бронкс, графстві Олбані. Схарактеризуємо соціальний контекст дискурсу, зосередивши увагу на його змінних ознаках. На лавці підсудних опинилися четверо поліцейських, які вистрілами (41 куля) вбили беззбройного злочинця у вестибюлі його власного будинку. Щодо історичної та культурної соціологем відзначимо, що в аналізований період (як і до сьогоднішньої доби) основним ціннісним пріоритетом американців стало поряд 3 іншими життя людини, а ідеологічною установкою, поширеною в суспільстві, - недопустимість перевищення поліцейськими своїх повноважень та боротьба з расизмом. Саме тому обвинувач протягом своєї промови неодноразово апелює до вказаних соціологем (напівжирним шрифтом в тексті нами виділені відповідні мовні одиниці):

In the 1990s in Bronx County, in Albany County, or anywhere else a human being should have been able to stand in the vestibule of his own home and not be shot to death, especially when those doing the shooting are police officers sworn to protect innocent people (Opening Statements. Amadou Diallo Trial).

у 1990-х роках в окрузі Бронкс, графстві Олбані або де-небудь ще, людина повинна була мати можливість стояти у вестибюлі власного будинку і не бути застреленою, особливо коли ті, хто робить стрілянину, - це поліцейські, які давали присягу захищати невинних (переклад тут і далі наш. - М. З., Л. П.).

Зауважимо, що прокурор акцентує саме вказану соціологему - він не зосереджує увагу на проблемі расизму, оскільки серед присяжних були і білі, і чорношкірі.

Змінні ознаки прагматичного контексту визначають специфіку наративу в декількох аспектах. Перший і головний із них - синкретизм функцій наративу і персуазиву. Якщо відштовхуватись від того, що наратив - розповідь із поясненням, то слід відзначити, що аналізована промова виходить за названі межі: від першого слова до останнього обвинувач використовує наратив для переконання, тобто для функції персуазиву. Фіксуємо важливу деталь: інтенції прокурора на кожному етапі чітко підпорядковані стратегічній меті: переконати присяжних, що 
підсудних слід визнати винними. Комунікативні стратегії і тактики варіюються в залежності від інтенцій прокурора на кожному етапі промови. На початку промови (уривок наведено вище) він намагається активізувати мисленнєву діяльність та збудити почуття присяжних, тому використовує стратагему «емпатія»: уявити себе на місці вбитого - це жахливо, отже, негативне ставлення до підсудних забезпечено. Далі 3 метою зображення вбитого як простої людини, що не відрізняється від пересічних американців, обвинувач подає деталі: скільки куль було в його тілі, де він проживав до загибелі, його вік, фізичні дані і т. ін. Стратегія деталізації поєднується з маніпулятивною стратегією, що реалізується у стратагемі «приховування»: у промові прокурора жодного разу не згадується про те, що вбитий був наркоманом, займався продажем не тільки відеокасет, а й наркотиків, що за ним давно вже стежила поліція. Інтенція посилення впливу реалізується через стратагеми «образний опис» та «приховування» (напівжирним шрифтом виділяємо в тексті мовні одиниці, що репрезентують стратагеми):

$<\ldots>$ he would be standing in the cold, clear night air in the vestibule of his home, unarmed, minding his own business and doing nothing wrong (Opening Statements. Amadou Diallo Trial).

<...> він стояв у холодному, прозорому нічному повітрі у тамбурі свого будинку, беззбройний, займаючись своїми справами і не роблячи нічого поганого.

Приховується інформація про те, що поганого міг зробити постраждалий (і робив часто). В останній частині наративу описуються дії поліцейських, деталі вбивства підозрюваного. Стратегія звинувачення реалізується через стратагеми «образний вплив», «негативна оцінка дій». Наприкінці обвинувач формулює мету свого виступу через стратагему «прохання», підкріплюючи його образною негативною оцінкою дій підсудних:

At the end of this case we will ask you to return a verdict based on the evidence. We ask you to find these defendants guilty of their intentional, depraved, reckless, unreasonable and unnecessary conduct that jeopardized the lives of Amadou Diallo's neighbors and destroyed Amadou Diallo's life (Opening Statements. Amadou Diallo Trial).

Наприкінці цієї справи ми попросимо вас винести вирок на основі доказів. Ми просимо вас визнати цих підсудних винними у їх умисній, розбещеній, необдуманій, необгрунтованій та непотрібній поведінці, яка поставила під загрозу життя сусідів Амаду Діалло та знищило життя Амаду Діалло.

Прокурор не вимагає, не закликає, а залишає за присяжними право на свободу дій і просить - це сильний комунікативний хід, проте він не часто використовується обвинувачами. За результатами аналізу промов у художніх кінофільмах (Devil's Advocate; Find Me Guilty) і творах (Harper) ми прийшли до висновку, що прокурори частіше звертаються із закликом 
бути об'єктивними, справедливими, але прямо про необхідність визнати підсудних винними не заявляють. Наприклад, у художньому кінофільмі «Find Me Guilty», знятому за реальними подіями, прокурор після образної розповіді про злочини мафіозного угруповання закликає до дій:

I am sorry, but the gravity of these atrocities against the people of our city, against all of America, demands action from you. You (Find Me Guilty).

Мені жаль, але тяжкість цих злочинів проти мешканців нашого міста, проти всієї Америки вимагає від вас дій. Від вас.

А в кінофільмі «Адвокат диявола» прокурор висловлює надію на те, що присяжні усвідомлять провину підсудного (вбивство трьох людей), а потім дякує їм за увагу:

And when the evidence is presented to you, when the fragmented details are woven together, you will realise that Alexander Kavin is guilty of the murder of three people. A cold-blooded murder with premeditated intent. Thanks (Devil's Advocate)

Аналіз лінгвального контексту показав, що основною специфічною ознакою судового наративу обвинувача $\epsilon$ поєднання опису подій 3 образною оцінкою, яка слугує для реалізації функції персуазиву. Образна оцінка іноді представлена імпліцитно, іноді - виражена експліцитно, але в будь-якому разі вона лейтмотивом проходить через увесь наратив. У першій частині виступу, яка присвячена розповіді про вбитого, негативна оцінка дій поліцейських представлена імпліцитно: слухачі вичитують її, спираючись на протиставлення очікуваних і реальних дій (це поліцейські, які давали присягу захищати невинних), пресуппозиційної інформації (...не бути застреленою і вестибюлі власного будинку - власний будинок сприймається як своєрідний оберіг; йому було всього 22 роки - молода людина має прожити своє життя). У другій частині, в якій розповідається про деталі вбивства, образні засоби мови виражені експліцитно. Деталізація у наративі - звичний засіб, але в устах прокурора інформація про деталі спрямована на реалізацію функції переконання. В арсеналі його образних засобів - не просто слова з негативною емоційною оцінкою, а такі, що акцентують увагу на деталях, які, з одного боку, суперечать ціннісним пріоритетам американців, а з другого, - посилюють негативну оцінку підсудних. Нагадаємо, що захист власності, iї недоторканість - одна із американських цінностей. Саме тому декілька разів повторюється займенник свій у різних граматичних формах та прикметник власний: $y$ вестибюлі власного будинку, свого будинку, прибув до своєї квартири, говорив з одним із своїх співмешканців. В окремих місцях промови обвинувач обходиться без займенника, але наголошує, що будинок був мешканням потерпілого: вийшли з машини перед будинком Амаду діалло. А якщо подати список лексем із негативною емоційною оцінкою, використаних для характеристики поліцейських та їхніх дій, то у присяжних може скластися враження, що вони просто зіткані із негативних рис: діяли безрозсудно і з розпусною байдужістю, винні у 
вбивстві та необдуманій загрозі життю людей, їхня поведінка була розбещена, необдумана, необгрунтована, непотрібна.

Точна інформація про кількість пострілів посилює протиставлення 3 кількістю тих, у кого стріляли, а Амаду Діалло був один: «Річард Мерфі чотири рази натискав на курок <...> Кеннет Босс п'ять разів <...> Шон Керролл та Едвард Макмеллон по 16 разів натискали на курок» (Ореning Statements. Amadou Diallo Trial)

Отже, специфіку наративу обвинувача становлять такі ознаки : апеляція до ідеологічних установок суспільства у відповідний історичний період (соціальний контекст дискурсу); синкретизм функцій наративу і персуазиву, використання як основної стратегії деталізації з акцентом на деталях, що свідчать про провину підсудних, звернення до маніпулятивних тактик, актуалізація стратагем «емпатія», «образна оцінка», «приховування окремих фактів» (прагматичний контекст); широке використання образних засобів мови 3 вираженою аксіологемою; імпліцитне протиставлення символів «оберіг» - «вбивство» (лінгвальний контекст). Перелічені ознаки виявлені в промовах обвинувачів і на матеріалі аналізу інших джерел; варіанти зафіксовані лише для останньої з них: протиставлення символів залежить від типу злочину. Узагальнивши об'єкти протиставлення, можна стверджувати, що опозицію становлять символи 3 аксіологемами «позитивне явище» (бажані умови, нормальні умови) - «негативне явище» (злочин).

Звернемось до аналізу змінних ознак наративу адвоката. Він працює в умовах того самого соціального контексту, що і прокурор, але його вихідна позиція набагато складніша: він має виконати свої функції попри ідеологічні установки та ціннісні пріоритети суспільства, віднайти ті основи, що поєднують захисника і присяжних та суддю. Виконання вказаних завдань забезпечує прагматичний контекст дискурсу. Адвокат починає свою промову із комунікативної стратегії зближення дистанції, використовуючи тактику самопрезентації із стратагемами «Я - такий, як ви всі: не робот, позбавлений емоцій, я хвилююсь»:

I have to confess that I'm a little nervous. It's not the camera. The cameras are here today and gone tomorrow. It is you 16 people or 12 of you who will be jurors that are really the only audience that matters. And you have my client, Sean Carroll's (Opening Statements. Amadou Diallo Trial).

Я повинен зізнатися, що трохи нервуюсь. Це не камера. Камери сьогодні тут, а завтра їх немає. Це ви 16 людей або 12 з вас, які будуть присяжними, насправді єдина аудиторія, яка має значення. Як і у вас, у мене доля, клієнт Шон Керролл.

У пошуках спільного між ним і присяжними адвокат звертається до тактики перебільшення i називає гарними людьми i вбитого, i поліцейських:

Ladies and gentlemen, this is a case about five good men. One of them was named Ahmed Diallo. The other four are named Sean Carroll, Kenneth Boss, 
Edward McMellon, and Richard Murphy (Opening Statements. Amadou Diallo Trial).

Пані та панове, це справа про п'ятьох добрих чоловіків. Одного з них звали Ахмед Діалло. Інших чотирьох називають Шон Керролл, Кеннет Босс, Едвард Макмеллон та Річард Мерфі.

Наступний намір адвоката - переконати аудиторію, що жахливий випадок - результат не злочину, а трагічних обставин, і про це він заявляє прямо. Щоб довести цю думку, адвокат ніби заповнює прогалини у виступі обвинувача, нагадуючи про професійні обов'язки поліцейських та їхні соціальні функції:

The facts will show, ladies and gentlemen, that four good officers are being prosecuted for something that happened while doing what we, the people, train them to do, with the weapons that we, the people, gave them, going where we, the people, wanted them and expected them to go(Opening Statements. Amadou Diallo Trial).

...чотирьох добрих офбіцерів переслідують за щось, що сталося під час того, що ми, люди, навчаємо їх робити, зі зброєю, яку ми, люди, дали їм, ідучи туди, де ми, людей, хотіли, щоб вони йшли. Бо, члени журі, доказом у цій справі є те, що цих чотирьох офіцерів ми послали до порушення.

I знову, як у виступі прокурора, в нагоді стає стратагема «емпатія»:

...we are going to try to put you in the shoes of those four officers, of these four officers, so that you can understand that situation (Opening Statements. Amadou Diallo Trial).

Пані та панове, ми спробуємо поставити вас на місце цих чотирьох офбіцерів, цих чотирьох офіцерів, щоб ви могли зрозуміти цю ситуацію.

Далі наратив наче б то реалізує свою основну функцію - розповідь із поясненням: адвокат детально описує труднощі служби поліцейських, ризики, на які вони йдуть заради громадського спокою. Проте сумніви щодо синкретичності функцій наративу і персуазиву зникають, i цьому сприяють стратагеми наступної частини виступу: «позитивна оцінка професійних і моральних рис підсудних», «негативна характеристика вбитого та його дій»:

The officers identified themselves with their shields out, as they are trained to do and as they do in every situation. Mr. Diallo doesn't listen to their clear orders to stop, which they are trained to give. He runs back into the vestibule. More orders to stop and to show his hands. "Show us your hands," something the officers are trained to do for their own protection. Again, Mr. Diallo does not comply. The officers pursue him with weapons drawn, as they are trained to do. He turns his back to them, runs for the inner door, and tries to enter the building (Opening Statements. Amadou Diallo Trial).

Офіцери назвали себе, виставляючи щити, як вони навчені робити, як і в кожній ситуації. Містер Діалло не слухає їх чітких наказів зупинитися, які вони навчені давати. Він біжить назад у тамбур. Більше 
наказів зупинитися і показати руки. «Покажіть нам руки», те, що офіцери навчені робити для власного захисту. Знову ж таки, пан Діалло цього не виконує. Офіцери переслідують його з витягнутою зброєю, як вони навчені. Він повертається до них спиною, біжить до внутрішніх дверей $i$ намагається увійти в будівлю.

Оцінка виражається у різні способи: в одних місцях наративу - за рахунок збудження асоціативної діяльності присяжних та судді через актуалізацію периферійних семантичних компонентів значень слів (захищали себе, як навчені робити), в інших - за допомогою прямих значень слів, у яких оцінна сема належить до пресуппозиційної інформації (Діалло не слухає, не виконує, повертається до них спиною). Показово, що у всіх випадках не останню роль відіграє когнітивна інформація, що $\epsilon$ важливою в певний історичний період. Так, словосполучення захищати себе в певних ситуаціях може актуалізувати і негативну оцінку, проте в судовому дискурсі, що стосується діяльності поліцейських, - тільки позитивну, що підтверджено регламентуючими документами США i пояснюється підвищеними ризиками професії поліцейського. Шлей позитивних асоціацій пов'язаний із словосполученням навчені робити воно актуалізує і повагу до професійних якостей, і позитивне визнання соціумом діяльності у відповідній сфері. Можливо, саме тому навчені повторюється в наративі неодноразово в різних варіантах.

Звертає на себе увагу ще одна особливість адвокатського наративу. Його розповідь має двовекторну спрямованість: з одного боку, вона виступає як інструмент персуазиву, з другого, - як засіб рефутативу, побудований на використанні стратагеми «спростування». Наративи обвинувачів і адвокатів створюють конкуренцію, ефект своєрідної битви наративів, на що звертали увагу науковці (Cotterill; Griffin). У битві виграє той, чий наратив сильніший. Якщо виокремити основні ідеї, які стверджував обвинувач, то виявляється, що кожна 3 них отримує спростування в промові адвоката. 3 метою підтвердження викладеної думки змоделюємо опозицію «акція - реакція», вибравши із промов обвинувача і адвоката висловлення з протилежними оцінками. Зауважимо, що нижче ми подаємо не переклад уривків із виступів, а узагальнені нами оцінні судження, які висловлювались агентами неодноразово протягом їхніх виступів (висловлення, подане в нашому перекладі, виділяємо курсивом та лапками). Позначимо твердження обвинувача як 0 , a спростування адвоката як А.

0: Вбитий був таким собі простим хлопцем, що продавав відеокасети і не робив нічого поганого. - А: Діалло викликав підозру офіцерів, проте не відреагував на команду зупинитися і показати руки, а натомість почав тікати.

О.: Поліцейські «діяли з безрозсудною байдужістю до життя Амаду та людей, які там жили». - А.: Поліцейські діяли так, як вони навчені. 
Наприкінці наративу адвокат не просить виправдати свого підзахисного, а продовжує спростування думок обвинувача 3 використанням стратагеми «образний вплив», яка актуалізується через асоціації з феноменом «кошмар»:

<...> Шон Керролл <...> потрапив у ситуацію, яка є кошмаром кожного хорошого поліцейського <..> I я сподіваюся, що ви вислухаєте докази і закінчите його кошмар. Дуже дякую.

Зауважимо, що в жодному із проаналізованих нами джерел адвокати не звертались до присяжних із прямим проханням виправдати їхніх підзахисних. У художньому творі Харпер Лі «Вбити пересмішника» адвокат просить присяжних бути об'єктивними і виконати їхній обов'язок іменем Бога (нагадаємо, що його мета не була досягнута через ідеологічні установки на расизм, актуальні в ту добу - 1960 рік). У кінофільмі за реальними подіями «Find me Guilty» адвокат (його функції взяв на себе сам головний підсудний) пропонує присяжним визнати винним його, а решту підсудних відпустити. У стрічці «Devil’s Advocate» адвокат просить подумати над питанням: чи можна звинувачувати безвинну людину за те, що ӥї не люблять:

I expect the only thing from you. That's it. Just one thing to ask yourselves: Is being unloved a reason enough to convict a man of murder? Have a nice lunch (Devil's Advocate).

Як видно з викладеного, специфіку наративу адвоката становлять такі ознаки: опора на ціннісні пріоритети суспільства, зокрема пов'язані з ознакою професійності (соціальний контекст); використання комунікативних стратегій зближення дистанції 3 аудиторією, комунікативної тактики апеляції до спільних моральних цінностей, стратагеми «емпатія», «образна оцінка», «раціональна оцінка», двовекторна спрямованість наративу - на персуазив і рефутатив (прагматичний контекст); актуалізація асоціативних семантичних компонентів значень слів та словосполучень, сем емоційної оцінки, повторюваність слів, що акцентують основні пріоритети суспільства. Всі названі ознаки зафіксовані і в промовах адвокатів на матеріалі судового дискурсу в інших джерелах.

Висновки та перспективи досліджень. Аналіз матеріалу підтвердив основоположну гіпотезу дослідження і дозволив встановити специфічні ознаки судового наративу. У ньому чітко виокремлюються ознаки двох типів: константні і змінні. До основних константних ознак судового наративу належать: тип судової системи (він визначає цільову аудиторію комунікативного впливу, а відтак - i його засоби); тема наративу (у будь-якому разі - розповідь про злочин, підсудного чи потерпілого); цілі учасників судового процесу (обвинувач - доводить провину, адвокат - їі відсутність або необхідність пом'якшення вироку); мовні формули етикету; інтертекстуальні зв'язки судового наративу (він завжди апелює до реальних фактів і нормативних текстів - законів, 
кримінального кодексу). Змінними $є$ комунікативні стратегії, тактики, ходи та їхнє мовне вираження, соціальні стереотипи, актуальні на відповідну історичну добу, національні ціннісні пріоритети. Наратив обвинувачів і адвокатів має спільні й відмінні ознаки. Спільні ознаки можна вважати специфічними для судового наративу загалом, до них належать апеляція до ідеологічних установок суспільства, його ціннісних пріоритетів; синкретизм функцій наративу й інших мовних жанрів; використання як основної стратегії деталізації з акцентом на деталях, що забезпечують досягнення іллокутивної мети; звернення до маніпулятивних тактик; актуалізація стратагем «емпатія», «образна оцінка». Основна специфічна ознака наративу обвинувача - синкретизм функцій наративу i персуазиву; адвоката - синктеризм функцій наративу, персуазиву i рефутативу.

Виступи обвинувачів і адвокатів створюють ефект своєрідної битви наративів, у якій виграє той, чий наратив сильніший. Впливову силу наративу зумовлює не тільки зміст виступів агентів, а ще й уміло поставлені запитання до свідків, відсутність комунікативного саботажу 3 боку свідків, а за його наявності - вміння йому протидіяти. До того ж за логікою предмету розгляду в судових процесах за господарчими або побутовими конфліктами полеміка адвокатів різних сторін має відрізнятися - відмінності поки що не виявлені. Названі аспекти можна згрупувати навколо проблем судового інтерв'ювання, та аргументації, які доповнюють наратив, - їх ми розглядаємо як перспективи дослідження обраної теми.

\section{Список використаних джерел}

Harper, Lee. To kill a mockingbird. Москва: Антология, 2016.

Opening Statements. The Amadou Diallo Trial. URL: criminaldefense.homestead.com/ diallo/htm.

The Diallo Verdict. URL: https://www.nytimes.com/2000/02/26/nyregion/diallo-verdictoverview-4-officers-diallo-shooting-are- acquitted-all-charges.html.

Devil's Advocate. URL: https://gidonline.io/film/advokat-dyavola/.

Find Me Guilty. URL: https://cutt.ly/znrqnvj.

\section{Sources}

Harper, Lee. To kill a mockingbird. Москва: Антология, 2016.

Opening Statements. The Amadou Diallo Trial. criminaldefense.homestead.com/ diallo/htm.

The Diallo Verdict. www.nytimes.com/2000/02/26/nyregion/diallo-verdict-overview-4officers-diallo-shooting-are- acquitted-all-charges.html.

Devil's Advocate. gidonline.io/film/advokat-dyavola/.

Find Me Guilty. https://cutt.ly/znrqnvj.

\section{Список використаної літератури}

Бистров, Яків. Англомовний біографічний наратив у вимірах когнітивної лінгвістики і синергетики. Івано-Франківськ, 2016.

Воеводин, Алексей. Стратагемы. Стратегии войны, манипуляции, обмана. Москва: Белые альвы, 2003. 
Георгієвська, К. Лінгвістичні особливості англомовного юридичного дискурсу. Записки 3 романо-германської філології, № 2 (43), 2019, с. 103-8. https://doi.org/10.18524/2307-4604.2019.2(43).186237.

Дейк, ван Т. А. Язык, познание, коммуникация. Москва, 1989.

Діомідова, Олена. Еволюція мовного дискурсу в судових промовах видатних юристів XIX - XX ст. Харків: «Друкарня Мадрид», 2015.

Доценко, Олена. Жанрова специфіка українського судового дискурсу. Мовні $i$ концептуальні картини світу: зб. наук. праць, вип. 24, ч.1, Київ, 2008, с. 269-80.

Зайцева, Маргарита, і Ліпко, Ірина. Специфіка мовних засобів та організація семантичного простору сугестивного дискурсу (на матеріалі текстів судових промов). Вісник Національного технічного університету України "КПІ". Серія: Філологія. Педагогіка, № 10, 2017, с. 26-30.

Карасик, Владимир. О типах дискурса. Языковая личность: институциональный $u$ персональный дискурс. Волгоград: Перемена, 2000, с. 5-20.

Кобзєва, Олена. Стратегії та тактики судді в американському судовому дискурсі: дис. ... канд. філол. наук: 10.02.04. Харків, 2017.

Куковська, Вікторія. Судова промова: експлікаційний наратив чи прихований діалог? Мова, № 27, 2017, с. 30-4. https://doi.org/10.18524/2307-4558.2017.27.107887.

Лисанець, Юлія. Медичний наратив як лінгвістична категорія. Науковий журнал Львівського державного університету безпеки життєдіяльності «Львівський філологічний часопис», № 3, 2018, с. 145-8.

Лингвистический энциклопедический словарь, под ред. В. Н. Ярцевой. Москва: Советская энциклопедия, 1990.

Литературный энциклопедический словарь, под ред. В. М. Кожевникова, П. А. Николаева. Москва: Советская энциклопедия, 1987.

Мінченко, Ольга. Загальнотеоретичні та методологічні засади системи юридиколінгвістичних знань. Київ, 2019.

Можейко, М. Нарратив. История философии. Энциклопедия. Минск: Интерпрессервис; Книжный Дом, 2002, с. 650-2.

Палашевская, Ирина. Судебный дискурс: функции, структура, нарративность. Автореф. дис. ...докт. філол. наук: 10.02.19. Волгоград, 2012.

Пелепейченко, Людмила. Умови реалізації впливового потенціалу наративу в соціальних комунікаціях. Вчені записки Таврійського національного університету імені В.І. Вернадського. Серія: Філологія. Соціальні комунікації, т. 31 (70), № 1, ч. 3, 2020, с. 46-51.

Прадід, Юрій. Юридична лінгвістика в Україні: здобутки і перспективи. Мовознавство, № 2, 2011, c. 31-7.

Царьова, Ірина. Лінгвопрагматичний аспект дослідження юридичного тексту. Вісник Запорізького національного університету. Філологічні науки, №1, 2019, с. 78-80. https://doi.org/10.26661/2414-9594-2019-1-17.

Чепелєва, Н., Смульсон, М., Шиловська, О., Гуцол, С. Наративні психотехнології. Київ: Главник, 2007. URL: https://cutt.ly/JbPC57t.

Burns, Robert. A theory of the trial. URL: https://cutt.ly/pbAwM7z.

Cotterill, Janet. Language and Power in Court. URL: https://cutt.ly/SbAefrb.

Griffin, Lisa. "Narrative, Truth, and Trial". The Georgetown Law Journal, vol. 101, 2013, pp. 281-335. URL: https://cutt.ly/AbAenej.

Herman, David. Basic elements of narrative. URL: https://onlinelibrary.wiley.com/doi/ book/10.1002/9781444305920.

Schiff, Brian. A New Narrative for Psychology. https://doi.org/10.1093/oso/ 9780199332182.001.0001 


\section{References}

Bystrov, Yakiv. Anhlomovnyi biohrafichnyi naratyv u vymirakh kohnityvnoi linhvistyky $i$ synerhetyky. Ivano-Frankivsk, 2016.

Voevodin, Aleksej. Stratagemy. Strategii vojny, manipuljacii, obmana. Moskva: Belye al'vy, 2003.

Georgievskaya, K. "Linguistic features of English Legal Discourse". Writings in RomanceGermanic Philology, no 2 (43), 2019, pp. 103-8. https://doi.org/10.18524/23074604.2019.2(43).186237

Dijk, Teun Adrianus Van. Jazyk. Poznanie. Kommunikacija. Moscow, 1989.

Diomidova, Olena. Evoliutsiia movnoho dyskursu v sudovykh promovakh vydatnykh yurystiv XIX-XX st. Kharkiv: “Drukarnia Madryd”, 2015.

Dotsenko, Olena. "Genre Specificity of Ukrainian Court Discourse". Linguistic and Conceptual Views of the World, iss. 24, part 1, Kyiv, 2008, pp. 269-80.

Zaitseva, Margaryta, and Lypko, Iryna. "Specificity of Language Means and Organization of the Semantic Space of the Suggestive Discourse". Journal of the National Technical University of Ukraine "KPI": Philology and Educational Studies, no. 10, 2017, pp. 26-30.

Karasik, Vladimir. "O tipah diskursa”. Jazykovaja lichnost': institucional'nyj i personal'nyj diskurs. Volgograd: Peremena, 2000, pp. 5-20.

Kobzieva, Olena. Judge's Strategies and Tactics in American Courtroom Discource. PhD Thesis. Kharkiv, 2017.

Kukovska, Viktoria. "Judicial Speech: an Explicative Narrative or a Hidden Dialogue?" Mova, no. 27, 2017, pp. 30-4. https://doi.org/10.18524/2307-4558.2017.27.107887.

Lysanets, Yuliia. "Medical Narrative as a Linguistic Category". Scientific jornal of the Lviv State University of Life Safety "Philological Periodical of Lviv", no. 3, 2018, pp. 145-8.

Lingvisticheskij jenciklopedicheskij slovar', edited by V. N. Jarceva. Moscow: Sovetskaja jenciklopedija, 1990.

Literaturnyy entsiklopedicheskiy slovar. edited by V. M. Kozhevnikov, P. A. Nikolayev. Moscow: Sovetskaja jenciklopedija, 1987.

Minchenko, Olga. Zahalnoteoretychni ta metodolohichni zasady systemy yurydykolinhvistychnykh znan. Kyiv, 2019.

Mozhejko, M. Narrativ. Istorija filosofii. Jenciklopedija. Minsk: Interpresservis; Knizhnyj Dom, 2002, s. 650-2.

Palashevskaja, Irina. Sudebnyj diskurs: funkcii, struktura, narrativnost'. Doctoral Thesis. Volgograd, 2012.

Pelepeychenko, Liudmyla. "Conditions of Implementing the Impact Potential of the Narrative in Social Communications". Scientific notes of V. I. Vernadsky Taurida National University. Series: Philology. Journalism, vol. 31 (70), no. 1, part. 3, 2020, pp. 46-51.

Pradid, Yurii. "Juridical Linguistics in Ukraine: Achievements and Perspectives". Movoznavstvo, no. 2, 2011, pp. 31-7.

Tsareva, Iryna. "Lingualpragmatic Aspect of the Legal Text Study". Bulletin Zaporizhzhia national university. Philological sciences, no. 1, 2019, pp. 78-80. https://doi.org/10.26661/2414-9594-2019-1-17.

Burns, Robert. A theory of the trial. cutt.ly/pbAwM7z.

Cotterill, Janet. Language and Power in Court. cutt.ly/SbAefrb.

Griffin, Lisa. "Narrative, Truth, and Trial". The Georgetown Law Journal, vol. 101, 2013, pp. 281-335. URL: https://cutt.ly/AbAenej.

Herman, David. Basic elements of narrative. onlinelibrary.wiley.com/doi/book/10.1002/ 9781444305920.

Schiff, Brian. A New Narrative for Psychology. https://doi.org/10.1093/oso/ 9780199332182.001.0001 